\title{
Okul Deneyimi Dersinin Öğrencilerin Öğretmenlik Algılarına Etkisi
}

\author{
Necla EKINCI \\ Muğla Sitkı Koçman Üniversitesi Eğitim Fakültesi \\ nekinci@mu.edu.tr \\ Semra TİCAN BAŞARAN \\ Muğla Sitkı Koçman Üniversitesi Ĕgitim Fakültesi \\ semrabasaran@mu.edu.tr
}

\section{$\ddot{O}_{z e t}$}

Bu çalışmanın amacı öğretmen yetiştirme programlarında yer alan Okul Deneyimi dersinin bu dersi alan okul öncesi öğretmenliği ögrrencilerinin 'ögrretmenlik algılarını' nasıl etkilediğini belirlemektir. Nitel araştırma yöntemlerinden durum çalışmasına dayalı olarak gerçekleştirilen araştırmanın verileri Muğla Sitkı Koçman Üniversitesi Ĕ̈itim Fakültesi Okul Öncesi Ĕ̈itimi Programında öğrenim gören üçüncü sinıf ögrencilerine dönem başında ve sonunda uygulanan "öğretmenlik algısı formu" aracıllğ ile elde edilmiştir. Araş̧ırma verileri 2012-2013 eğitim yllı güz döneminde yapılan uygulamalardan elde edilmiştir. Elde edilen metinler, nitel veri çözümleme tekniklerinden içerik analizi kullanılarak çözümlenmiştir. Araştırma bulguları okul deneyimi dersini alan ögrencilerin öğretmenlik algısına yönelik tanımlamalarının sayıca arttığını ve bu tanımlamalarının nitelik olarak da derinleştiğini ortaya koymaktadır.

Anahtar sözcükler: Okul deneyimi, öğretmenlik alglsl, okul öncesi ĕgitimi.

\section{The Effect of School Experience Course on Teaching Perceptions of Pre-Service Teachers}

\begin{abstract}
The purpose of this study is to investigate how school experience course affects the 'teaching perceptions' of pre-school education students took this course. The data of this qualitatively designed case study were obtained through the administration of "teacher perceptions' form" to the third year students of PreSchool Education Program of Education Faculty at Muğla Sitkı Koçman University at the beginning and at the end of 2012-2013 fall semester. Content analysis was applied in the data analysis. The research findings revealed that the descriptions defining teaching perceptions of students took school experience course increased quantitatively and the quality of these descriptions got deeper as a result of this experience.
\end{abstract}

Keywords: School experience, teaching perceptions, pre-school education 


\section{Giriş}

Günümüzde toplumlar yaşamakta oldukları hızlı ve büyük değişimleri yönetebilmek ve geleceklerine yön verebilmek için ihtiyaç duydukları nitelikli insan kaynağını oluşturabilmenin en önemli aracı olarak eğitim sistemlerini görmekte ve eğitim sistemlerinde niteliği arttırmaya yönelik reformlara yönelmektedirler. Eğitim reformlarının önemli bir bölümü öğretmenlerin niteliğini arttırmaya yöneliktir çünkü "öğretmen" eğitimde sistemin işleyişini ve niteliğini belirleyen unsurların başında gelmektedir (Özdemir ve Çanakçı, 2005; Oğuz, 2004). Niteliği geliştirmenin odağında öğretmen olması dikkatleri öğretmen yetiştirme programlarına çekmektedir. Öğretmen yetiştirmede niteliği yükseltmek ve bunun sürekliliğini sağlamak alan bilgisi, genel kültür ve meslek bilgisi boyutlarını içeren bütüncül bir yaklaşımla düzenlenmiş iyi bir hizmet öncesi eğitim ile mümkün görülmektedir (Sözer,1990).

Öğretmen eğitiminin teori ve pratiği arasındaki uyumsuzluklarla ilgili çalışmalar ve tartışmalar öğretmen yetiştirme sürecinde bu durumun gözden geçirilmesine dayanak oluşturmuştur. Bu bağlamda 1994-1997 yılları arasında YÖK Dünya Bankası işbirliği ile yürütülen Millî Eğitimi Geliştirme Projesi çerçevesinde yapılan değerlendirmeler sonucunda, öğretmen adaylarının öğretmenlik mesleğinin uygulanmasına yönelik bilgi ve beceri açısından eksikliklerinin olduğu anlaşılmış ve projenin hemen sonrasında öğretmen adaylarının kuramsal bilgi ve becerilerini gerçek bir okul ortamında uygulayabilmeleri, öğretmenlik mesleğini farklı yönleriyle tanıyabilmeleri ve mesleğe hazırlanmalarına firsatlar sunmak amacıyla öğretmen yetiştirme programlarına uygulamaya dönük dersler konulmuştur (Oğuz, 2004; Sarıtaş, 2007). Okul uygulama derslerinden birisi olan "Okul Deneyimi" dersi, öğretmen adaylarına, okul örgütü ve yönetimi ile okullardaki günlük yaşamı tanıma, eğitim ortamlarını inceleme, ders dışı etkinliklere katılma, deneyimli öğretmenleri görev başında gözleme, öğrencilerle bireysel ve küçük gruplar halinde çalışma ve kısa süreli öğretmenlik deneyimleri kazanma olanağı veren, onların öğretmenlik mesleğini doğru algılayıp benimsemelerini sağlayan bir derstir (MEB, 1998). 2006'da yapılan son düzenlemeler sonrası söz konusu ders 1 saati teorik, 4 saati uygulama okulu kurumlarında gözlem ağırlıklı bir ders olarak yerini almıştır. Dersin teorik bölümü yapılan uygulamaların değerlendirilmesi ve sonraki uygulamaların planlamasını içermektedir (YÖK, 1998 ).

Alanyazın incelendiğinde okul deneyimi dersinin; öğrencilerin, öğretmen niteliklerini tanıma, mesleği yapabileceğine olan inancın artması, mesleğin önemini fark etme, öğrenciyi tanıma, öğrenciöğretmen-veli-yönetici değişkenleri arasındaki iletişim biçimleri hakkında bilgi sahibi olma, aidiyet duygusu kazanma, mesleki yeterlikler boyutuna ilişkin algılarında yükselme, öğretmen olmanın farkına varma, çekingenlik, ürkeklik, endişe, korku ve kaygıları aşma, mesleki bilgi bakımından eksiklerini görme, okul ortamını tanıyarak eğitime daha gerçekçi bakma, okul yönetimi hakkında gerçek bilgileri alma, sınıfta disiplini sağlama, ilgiyi sürekli canlı tutabilmek için gerekli motivasyon tekniklerini gözlemleme, beden dilinin ders içinde nasıl daha etkili olarak kullanılabileceğini gözlemleme, değişik yöntem, teknik ve araç gereç kullanmanın önemli ve etkili olduğunu anlama, çocukları sevme ve onlarla ilgilenmenin hem disiplin sorunlarını çözme hem de zevkli ders yapma açısından etkili olduğunu görme, vb. sonuçların olduğu araştırmalarla desteklenmektedir (Demircan, 2007; Oğuz, 2004; Ergün ve Özdaş, 1999). Öte yandan dersin kazandırdıklarının yanında süreçte öğretmen adaylarının okul idaresi ve uygulama öğretmeni ile sorunlar yaşadıklarını (Ören ve diğerleri, 2009), öğretmenleri iyi bir model olarak görmediklerini (Turgut, Yılmaz ve Firuzan, 2008), Azar da (2003) uygulama öğretmeninin seçiminde belli ölçütler aranmadığını, işi gerektiği gibi yerine getiremeyecek öğretmenlerin seçildiğini belirtmektedir.

Ergün ve Özdaş (1999) ise öğretmen adaylarının, uygulama öğretmenlerinin kendilerini hayal 
kırıklığına uğrattığını, büyük çoğunluğunun idealist olmadığını, bilgi ve genel kültür açısından yetersiz kaldıkları, kendilerini yenilemedikleri, mesleklerini sevmedikleri, öğrenci psikolojisini bilmedikleri, öğrencilerini azarlayıp, korkutup, dövdükleri, öğrencilere eşit davranmadıkları, notu bir silâh olarak kullandıkları, öğrencilerde kendine güven duygusunu geliştiremedikleri, zamanında derse girmedikleri, birçok ders saatinin boşa geçtiği, öğretmenlerin öğrencileri birçok olumsuz sıfatlarla etiketledikleri, derslere hazırlıklı girmedikleri, planlamanın gereğine inanmadıkları, planları formalite ve yasak savmacı bir düşünceyle yaptıkları, öğrencileri etkin hale getiremedikleri, öğrencinin seviyesine inemedikleri, motivasyonun düşük kaldığı, öğrenci başarısını objektif bir biçimde ölçemedikleri ve öğrenci velileriyle fazla ilgilenmedikleri gibi olumsuz saptamalarda bulunmuşlardır.

İşlevsel bir öğretmenlik eğitimi programının temel dayanağı olan uygulama derslerinin nitelikli öğretmen yetiştirmede beklenen temel katkılarından birisi öğretmen adaylarının mesleğe dönük algılarını geliştirmektir. Buradan hareketle, bu çalışmanın amacı eğitim fakültelerinin öğretmen yetiştirme programlarında yer alan Okul Deneyimi dersinin bu dersi alan okul öncesi eğitimi programı öğrencilerinin 'öğretmenlik algılarını' (etkili ve yetersiz öğretmen ) nasıl etkilediğini belirlemektir.

\section{YÖNTEM}

\subsection{Araştırma Modeli}

Bu çalışmada nitel araştırma yöntemlerinden durum çalışması yöntemi benimsenmiştir. Durum çalışmalarında belirli bir duruma ilişkin etkenler bütüncül bir yaklaşımla derinlemesine incelenerek ilgili durum hakkında sonuçlar ortaya koymak hedeflenir (Yıldırım ve Şimşek, 2013). Amaç, genellemelere ulaşmak değil var olan durumu en iyi şekilde betimlemektir.

\section{2. Çalışma Grubu}

Araştırmada kolay ulaşılabilir örneklem tekniğinden faydalanılmıştır. Bu örneklem tekniğinde amaç ulaşılabilir ve gönüllü olan katılımcılarla araştırmayı yürütmektir (Creswell, 2005). Buradan hareketle, 2012-2013 akademik yılı güz döneminde Muğla S1tkı Koçman Üniversitesi Eğitim Fakültesi Okul Öncesi Eğitimi Programında Okul Deneyimi Dersini alan öğrencilerden 27'si kız, 3'ü erkek, toplam 30 gönüllü öğrenci çalışma grubunu oluşturmuştur.

\subsection{Veri Toplama Aract}

Veri toplama aracı olarak Selçuk (2001) tarafından Okul Deneyimi Dersi kapsamında yapılacak etkinliklerde kullanılmak üzere önerilen ve nitelikli bir sınıfın, etkili bir öğretmenin, mükemmel bir dersin, yetersiz bir sınıfın, yetersiz bir öğretmenin ve verimsiz bir dersin özelliklerine yönelik altı açık uçlu soru yer alan "Öğretmenlik Algısı Formu" kullanılmıştır.

$\mathrm{Bu}$ makale formda yer alan boyutlardan etkili ve yetersiz bir öğretmenin özellikleri ile sınırlı tutulmuştur.

Teddlie ve Tashakkori'ye göre (2009) nitel araştırmalarda güçlü yorumların yapılması elde edilecek nitelikli veriler ile mümkündür. İnanılırlık nitel çalışmalarda güvenilirliğin önemli bir göstergesidir. Nicel çalışmalarda iç geçerliği sağlama yolları olarak görülen uzman görüşleri ve üçgenleme (çeşitleme) teknikleri nitel çalışmalarda inanılırlığı güçlendirme yöntemlerindendir. Bu doğrultuda bu çalışmada; kullanılan veri toplama aracının iç geçerliğini sağlamak için uzman görüşüne başvurulmuştur. Buna ek olarak her bir boyut için hem olumlu hem de olumsuz görüşler sorulup, veri çeşitlemesi sağlanarak güvenilirliğin arttırılması hedeflenmiştir.

Veriler, 2012-2013 akademik yılı güz döneminin ilk haftasında yapılan ilk uygulama ve dönemin son haftası yapılan ikinci uygulama ile toplanmıştır.

\subsection{Verilerin Çözümlenmesi}


Elde edilen verilerin çözümlenmesinde içerik analizi kullanılmıştır. Her bir boyutta verilen cevap metinler birkaç kez dikkatlice okunmuş ve kavramlar kodlanmıştır. Ortaya çıkan kodlar benzerlikleri ve birbirleriyle ilişkileri göz önünde bulundurularak temalar oluşturulmuş, görüşler bu temalara yerleştirilmiştir. Çözümlemeler sırasında ele edilen kodlar sürekli olarak karşılaştırılmıştır. $\mathrm{Bu}$ karşılaştırmalar, yığın halindeki verilerin daha net ve öz bir şekilde ortaya konulmasını sağlamaktadır (Kvale, 1996). Nitel çalışmalarda inanılırlığı güçlendirme yollarından birisi veri toplama ve analizi sürecine bir başka bireyi; "tarafsız" bir başka denk araştırmacıyı sürece katmaktır. Önyargısız bu denk araştırmacı ile, elde etme ve analiz etme sürecinde nitel veriler hakkındaki diyalog araştırmacının yorumlarını netleştirmesini ve olası yanlılık kaynaklarını tespit etmesini sağlar (Teddlie ve Tashakkori, 2009). Bu doğrultuda, analiz sürecinde; veriler her iki araştırmacı tarafından ayrı ayrı değerlendirilmiş ve daha sonra bir araya gelinerek temalar ve altlarında yer alan kodlar bazında sürekli yapılan karşılaştırmalarla en doğru yargılara ulaşılmaya çalışılmıştır. Araştırmacıların ikilemde kaldığı durumlar tekrar gözden geçirilmiş ve ortak bir fikir birliğine varıncaya kadar verilerdeki gerekli yerler incelenmiştir. Nitel araştırmalarda bulguların sayısal niceliklerle de desteklenmesi araştırmaların güvenilirliğini arttırma, verilerin yorumlanmasında nesnelliği arttırma ve tema ve kategoriler arasında karşılaştırmalar yapma imkânı sağlaması açısından önemlidir (Yıldırım ve Şimşek, 2013). Bu doğrultuda, araştırmada elde edilen veriler, tekrar edilme sıklığı belirtilerek sayısal değerlerle desteklenmiştir. Ayrıca, yapılan yorumları desteklemek ve katılımcıların bakış açılarını doğrudan yansıtabilmek amacıyla kimi zaman cevap metinlerinden doğrudan alıntılara yer verilmiştir.

\section{BULGULAR ve YORUM}

\subsection{Etkili Bir Ö̆̆retmenin Özellikleri}

Okul öncesi eğitimi öğretmenliği öğrencilerinin okul deneyimi dersini aldıkları dönemin başındaki ve sonundaki etkili öğretmenin özelliklerine ilişkin görüşleri Tablo 1'de sunulmuştur.

\section{Tablo 1. Etkili Bir Öğretmenin Özelliklerine İlişkin Görüşler}

\begin{tabular}{|c|c|c|c|}
\hline Dönem Başındaki Görüşler & $\mathbf{f}$ & Dönem Sonundaki Görüşler & $\mathbf{f}$ \\
\hline Kişisel Özellikler & 49 & Kişisel Özellikler & 61 \\
\hline Mesleğini sever & 9 & Mesleğini sever ve saygı duyar & 9 \\
\hline Sabırlı ve hoşgörülüdür & 6 & Sabırlı ve hoşgörülüdür & 9 \\
\hline Çocuklara iyi bir modeldir & 4 & Her yönüyle çocuklara olumlu bir modeldir & 10 \\
\hline \multirow[t]{4}{*}{ Anlayış̧ıdır } & 3 & Cocuklara karşı anlayışlıdır & 4 \\
\hline & & Empati gücü yüksektir & 5 \\
\hline & & Özel hayatını sınıfa yansıtmaz & 2 \\
\hline & & Davranışlarında tutarlı ve kararlıdır & 2 \\
\hline Mesleki Gelişim & 20 & Mesleki Gelişim & 17 \\
\hline Alanında kendini iyi yetiștirmiștir & 7 & & \\
\hline $\begin{array}{l}\text { Alanındaki geliş̧meleri takip eder, kendini sürekli } \\
\text { geliştirir, }\end{array}$ & 6 & Mesleki anlamda kendini sürekli yeniler ve geliştirir & 8 \\
\hline Değişime ve yeniliklere açıktır & 3 & Yeniliklere açıtır & 5 \\
\hline İletişim Becerileri & 18 & İletişim Becerileri & 17 \\
\hline Öğrencileri ile iletişimi iyidir & 11 & Öğrencilerle iyi bir iletişim kurar & 8 \\
\hline \multirow[t]{5}{*}{ Veliler ile sürekli iletişim içindedir } & 2 & Çocuklarla göz teması kurar & 4 \\
\hline & & Velilerle İletişim & 4 \\
\hline & & Veliler ile iyi bir iletişim içindedir & 2 \\
\hline & & Velileri de çocuğun öğrenme sürecine katar & 1 \\
\hline & & Gerekirse velileri eğitir & 1 \\
\hline Öğrenciyi Tanıma & 26 & Öğrenciyi Tanıma & 29 \\
\hline Öğrencilerini iyi tanır & 11 & Çocukları çok iyi tanır & 12 \\
\hline Bireysel farklılıkların farkındadır & 4 & Çocukların bireysel farklılıklarının farkındadır & 10 \\
\hline İyi bir gözlemcidir & 8 & İyi bir gözlemcidir & 5 \\
\hline Öğrenciye Değer Verme & 31 & Öğrenciye Değer Verme & 32 \\
\hline
\end{tabular}




\begin{tabular}{|c|c|c|c|}
\hline $\begin{array}{l}\text { Çocukları sever } \\
\text { Çocuklara ve fikirlerine saygı duyar }\end{array}$ & $\begin{array}{l}7 \\
4\end{array}$ & $\begin{array}{l}\text { Çocukları sever } \\
\text { Öğrencilerine ön yargılı davranmaz, ayrım yapmaz } \\
\text { Çocuklara değerli olduklarını hissettirir } \\
\text { Çocuklara karşı dürüsttür }\end{array}$ & $\begin{array}{r}10 \\
7 \\
2 \\
1 \\
\end{array}$ \\
\hline $\begin{array}{l}\text { Planlama } \\
\text { Derse hazırlıklı gelir }\end{array}$ & $\begin{array}{r}27 \\
9\end{array}$ & $\begin{array}{l}\text { Planlama } \\
\text { Planlı ve programlıdır } \\
\text { Planları ve etkinlikleri kendisi hazırlar } \\
\end{array}$ & $\begin{array}{r}16 \\
6 \\
3 \\
\end{array}$ \\
\hline $\begin{array}{l}\text { Öğrenme Öğretme Süreci } \\
\text { Sinıfın fiziksel düzenini iyi yapar }\end{array}$ & $\begin{array}{r}28 \\
3\end{array}$ & $\begin{array}{l}\text { Öğrenme Öğretme Süreci } \\
\text { Çocukların bireysel farklılıkları ve gelişim özelliklerine } \\
\text { uygun etkinlikler yapar }\end{array}$ & $\begin{array}{r}38 \\
5\end{array}$ \\
\hline $\begin{array}{l}\text { Sınıfın fiziksel imkânlarını en iyi şekilde kullanır } \\
\text { Merak ve ilgi uyandırır } \\
\text { Etkin katılımı sağlar } \\
\text { Öğretim yapmaz öğrenmeye rehberlik eder } \\
\end{array}$ & $\begin{array}{l}2 \\
2 \\
2\end{array}$ & $\begin{array}{l}\text { Çocukların bireysel farklılıkları ve gelişim özelliklerine } \\
\text { uygun ögrenme ortamları oluşturur } \\
\text { Sınıfta ilgi ve merak uyandıran bir atmosfer oluşturur } \\
\text { Çocukların etkin katılımına olanak sağlar } \\
\text { Öğrenmeye teşvik edicidir }\end{array}$ & $\begin{array}{l}3 \\
3 \\
3\end{array}$ \\
\hline $\begin{array}{l}\text { Sinıf Yönetimi } \\
\text { Sınıfa hâkimdir } \\
\text { Demokratik bir ortam oluşturur }\end{array}$ & $\begin{array}{r}19 \\
9 \\
6\end{array}$ & $\begin{array}{l}\text { Sınıf Yönetimi } \\
\text { Sınıfa hâkimdir } \\
\text { Demokratiktir } \\
\text { Sınıf yönetimi konusunda yeterli bilgi ve deneyime } \\
\text { sahiptir } \\
\text { Sınıf kurallarını (öğrencilerle) oluşturur } \\
\text { Sınıf kurallarını ögrencilerin içselleștirmesini sağlar }\end{array}$ & $\begin{array}{r}19 \\
5 \\
3 \\
3\end{array}$ \\
\hline $\begin{array}{l}\text { Zaman Yönetimi } \\
\text { Zamanı verimli kullanır } \\
\end{array}$ & $\begin{array}{l}7 \\
7 \\
\end{array}$ & $\begin{array}{l}\text { Zaman Yönetimi } \\
\text { Zamanı verimli kullanır }\end{array}$ & \\
\hline Toplam & 225 & & 241 \\
\hline
\end{tabular}

Tablo 1 incelendiğinde okul öncesi eğitimi öğretmenliği öğrencilerinin etkili öğretmenin özelliklerine ilişkin okul deneyimi dersini aldıkları dönemin başındaki ve sonundaki görüşlerinin kişisel özellikler, mesleki gelişim, iletişim becerileri, ögrenciyi tanıma, ögrenciye değer verme, planlama, öğrenme ögretme süreci, sınıf yönetimi ve zaman yönetimi başlıklarında gruplandı̆̆ 1 görülmüştür. Dönem sonundaki görüşlerinin $(\mathrm{f}=241)$ dönem başındaki görüşlerine $(\mathrm{f}=225)$ göre genel olarak hem sayıca hem de kapsam olarak genişlediği görülmektedir. Öğrencilerin dönem sonunda mesleki gelişim ve planlama boyutundaki görüşleri azalmıştır. Ayrıca öğretmen adayları, okul deneyimi ders süreci sonunda başlangıçta olmayan velilerle iletişim kurma boyutunu süreç sonucunda etkili bir öğretmende bulunması gereken önemli bir özellik olarak görmüşlerdir. Öğrenci görüşlerini ortaya koyan söz konusu temalar, MEB (2008) tarafindan tanımlanan, genel öğretmen yeterlikleri ve okul öncesi öğretmenliği özel alan yeterlikleri ile büyük oranda örtüşmektedir ki bu durum dersin öğrencilerin algılarına olan etkilerini göstermektedir.

Tablodan etkili bir öğretmenin özellikleri ile ilgili olarak kişisel özellikler hem dönem başında hem de dönem sonunda en sık ifade edilen temadır. Kişisel özellikler teması altında dönem başında ve sonunda mesleğini sever, sabırlı ve hoşgörülü̈ür, anlayışlıdır ve çocuklara iyi bir modeldir ifadeleri öne çıkan görüşlerdir. Bu bulgu öğretmenin kişisel özelliklerine yönelik yapılan çalışmaların sonuçları ile benzerlik göstermektedir (Tarman, 2012; Çicek, Başaran, Demirbaş ve Maden, 1999). Dönem sonunda bu görüşlerin sıklığının ve yapılan vurguların arttığı dikkati çekmektedir ki bu durum çocuklara model olma ile ilgili görüşte açıkça görülmektedir. Mesleğini severek yapma görüşü ilgili olarak K:22 etkili bir öğretmeni "işini seven ve öğretmenliğin kutsallığının bilincindedir" ifadesi ile dönem sonunda görüşlerin vurgusunun arttığına bir örnek olarak değerlendirilebilir. Dönem başındaki görüşlerden farklı olarak dönem sonunda ifade edilen görüşlerden empati gücü yüksektir, sıklıkla ifade edilen bir görüştür. Bu görüş ile ilgili olarak K:17'nin “çocuklarla birlikteyken çocuk olabilen”, K:5'in "olaylara zaman zaman öğrenci gözüyle bakabilen" ve K:3'ün "öğrencilerin dilinden anlar" ifadeleri dönem sonunda etkili öğretmenin kişisel özellikleri ile ilgili görüşlerin mesleğe yönelik farkındalıklarının arttığını göstermektedir. 
Illetişim becerileri ile ilgili görüşlerin sayısında dönem sonunda belirgin bir farklılaşma görülmezken, dönem başında ifade edilen veliler ile sürekli iletişim içindedir görüşüne, velileri de çocuğun ögrenme sürecine katar ve gerekirse velileri de eğitir görüşleri de eklenerek yeni bir temanın oluşturulmuş olması dikkat çekicidir. Okul öncesi dönemde aile ile işbirliği öğrenmede kalıcıllı̆̆ sağlamak açısından önemlidir. Bu konuda Bilgin (2010), öğretmen öğrencilerini tek tek tanıdığ 1 ve onların aileleri ile etkin iletişim içinde bulunduğu takdirde okul ortamı öğrenci için gerçek bir eğitim ve düzen ortamı olacaktır ve çocuğun gelişimi, sosyalleşmesi ve olgunlaşması doğru şekilde destekleneceğini ifade etmektedir.

Öğrenciyi tanıma boyutunda dönem başında ve dönem sonunda benzer görüşler öne çıkarken, dönem sonunda çocukların bireysel farklılıklarının farkındadır görüşünün sıklığının arttı̆̆ı görülmektedir. Bireysel farklılıklarının farkında olma ile ilgili olarak K:8'in "öğrencilerin bireyselliklerine odaklanarak, hepsinden aynı beklentilerde bulunmaz, kesin kalıplarda bireyler olmasını beklemez" şeklindeki ifadesi etkili bir öğretmenin özelliklerinin dönem sonunda detaylandırıldığının görülmesi bakımından önemlidir. İyi bir gözlemci olma ile ilgili olarak K: 12'nin etkili bir öğretmen "iyi bir gözlemci ve yetenek avcısıdır" ifadesi sınıf ortamında öğrenciyi tanıma ve bireysel özelliklerinin farkına varılmasına dönük çabaların, bir öğretmenin daha etkili olarak algılandığını göstermesi bakımından önemlidir. Bireyi tanımanın en önemli amacı, onun gelişmesine ve uyum göstermesine yardımcı olmaktır. Ayrıca eğitim ortamında yeterince yararlanabilmesi içinde bireyi tanımak gerekmektedir. Çünkü her birey kendine özgü, biricik ve eşi bulunmayan bir varlıktır ( Tagay, 2014).

Ögrenciye değer verme boyutunda dönem başında ve sonunda çocukları sever öne çıkarken dönem sonunda öğrencilerine önyargılı davranmaz, ayrım yapmaz görüşüne vurgu artmıştır.

Mesleki gelişim ile ilgili dönem sonundaki görüşlerde bir farklılık görülmemektedir. Bununla birlikte dönem sonuna göre sayıca artışın olduğu mesleki anlamda kendini sürekli yeniler ve geliştirir görüşü, Haktanır'ın (2008), araştırmasındaki aday öğretmenlerin iyi bir okul öncesi öğretmeninin sürekli kendini geliştiren, yenileyen bir kişi olması gerektiğine ilişkin görüşleri ile benzerlik göstermektedir.

Planlama ile ilgili olarak öğrencilerin dönem sonundaki görüşleri ile dönem başındaki görüşleri benzerlik göstermekle birlikte, görüşlerin sayısındaki azalma ve dönem sonundaki planları ve etkinlikleri kendisi hazırlar şeklindeki ek görüş dikkat çekicidir.

Öğrenme ögretme süreci diğer temalara göre hem dönem başında hem de dönem sonunda ifade edilme sıklığı yüksek ve dönem sonunda ifade edilme sıklığı oranının en fazla arttığı temadır. Bu boyutta öğrencilerin dönem başında sınıfin fiziksel düzenini iyi yapar ve sinıfin fiziksel imkanlarını en iyi şekilde kullanır gibi fiziki koşullar ile ilgili görüşleri ön plan çıkarken dönem sonunda, çocukların bireysel farklılıkları ve gelişim özelliklerine uygun etkinlikler yapar ve çocukların bireysel farklılıkları ve gelişim özelliklerine uygun ögrenme ortamları oluşturur gibi çocuğu merkeze alan görüşlerinin ön plana çıktığı anlaşılmaktadır.

Sınıf yönetimi ile ilgili görüşlerin dönem başında ve sonunda sayıca aynı olmakla beraber sınıf kurallarını ögrencilerle birlikte oluşturma, sınıf kurallarını öğrencilerin içselleştirmesini sağlar ifadeleri görüşlerin çeşitliliğin arttı̆̆ını göstermesi bakımından önemlidir.

Tablo 1'deki kişisel özellikler, ögrrenme öğretme süreci, ögrrenciyi tanıma, ögrenciye dĕger verme, zaman yönetimi ve sinıf yönetimi temalarının sayıca ve kapsam olarak artması ile ilgili bulgulara dayalı olarak, dersin öğrencilerin öğretmenlik algılarının gelişmesine katkı sağladığı şeklinde değerlendirilebilir. Oğuz (2004) ile Oral ve Dağlı (1999) yaptıkları araştırmada okul deneyimi dersinin öğretmen adaylarının mesleki yeterlikler boyutuna ilişkin algılarını yükselttiği sonucuna ulaşmışlardır. Demircan'ın (2007) araştırmasında öğrenciler, dersin öğretmen niteliklerini tanımaya katkı sağladığını belirtmişlerdir. Öte yandan, mesleki gelişim ve planlama temalarındaki 
algılarına benzeri bir etkinin gerçekleşmediği söylenebilir.

\subsection{Yetersiz Bir Öğretmenin Özellikleri}

Okul öncesi eğitimi öğretmenliği öğrencilerinin okul deneyimi dersini aldıkları dönemin başındaki ve sonundaki yetersiz öğretmenin özelliklerine ilişkin görüşleri Tablo 2'de sunulmuştur.

\section{Tablo 2. Yetersiz Bir Öğretmenin Özelliklerine İlișkin Görüşler}

\begin{tabular}{|c|c|c|c|}
\hline Dönem Başındaki Görüsşler & $\mathbf{f}$ & Dönem Sonundaki Görüşler & $\mathbf{F}$ \\
\hline Kişisel Özellikler & 32 & Kişisel Özellikler & 40 \\
\hline Mesleğini, işini sevmez & 10 & Mesleğini, işini severek yapmaz & 9 \\
\hline Öğrencilerine olumlu model olmaz & 3 & Çocuklara olumsuz bir modeldir & 3 \\
\hline \multirow[t]{4}{*}{ Mesleğinde yorulmuştur } & 1 & Mesleğinden bıkmıştır & 2 \\
\hline & & Mesleğinin öneminin farkında değildir & 2 \\
\hline & & Empati kuramaz & 2 \\
\hline & & Dış görünüşüne önem vermez & 3 \\
\hline Mesleki Gelişim & 21 & Mesleki Gelişim & 20 \\
\hline Kendini yenilemez, yineler & 10 & Kendini yenilemez, yineler & 8 \\
\hline Yeterli bilgiye sahip değildir, alana hâkim değildir & 9 & Yeterli bilgi ve deneyime sahip değildir & 8 \\
\hline İletişim Becerileri & 20 & İletişim Becerileri & 21 \\
\hline Öğrencileri ile iyi bir iletişim kuramaz & 10 & Öğrencileri ile iyi iletişim kuramaz & 10 \\
\hline Öğrencileri ile göz teması kurmaz & 1 & Öğrencileri ile göz teması kurmaz & 3 \\
\hline Sesini iyi kullanamaz & 3 & Sesini iyi kullanamaz & 2 \\
\hline Çocukları dinlemez & 4 & Öğrencileri ile sevgi bağı kuramaz & 1 \\
\hline Veliler ile İletişim & 2 & Veliler ve Okul Çevresi ile İletişim & 3 \\
\hline \multirow[t]{2}{*}{ Veliler ile iyi iliş̧kiler kuramaz } & 2 & Veliler ile iyi ilişkiler kuramaz & 2 \\
\hline & & Okul çevresi ve veliler ile etkin bir yapı kuramaz & 1 \\
\hline Öğrenciyi Tanıma & 10 & Öğrenciyi Tanıma & 16 \\
\hline Öğrencilerini tanımaz & 5 & Öğrencilerini tanımaz, özelliklerinin farkında değildir & 7 \\
\hline Öğrencilerini iyi gözlemleyemez & 3 & Öğrencilerini iyi gözlemleyemez & 3 \\
\hline \multirow[t]{2}{*}{ Çocukların gelişim özelliklerini bilmez } & 2 & Çocukların gelişim özelliklerini bilmez & 4 \\
\hline & & Çocukların gelişimini takip etmez & 1 \\
\hline Öğrenciye Değer Verme & 25 & Öğrenciye Değer Verme & 27 \\
\hline Cocukları sevmez & 9 & Çocukları sevmez & 3 \\
\hline Öğrencileri arasında ayrımcılık yapar & 5 & Çocuklara eşit ve adil davranmaz & 7 \\
\hline Öğrenciyi anlayamaz & 3 & Ögrencilerini anlamaz & 2 \\
\hline \multirow[t]{2}{*}{ Çocuklara sevgi ve şefkatle yaklaşmaz } & 2 & Çocukları kırıcı, rencide edici davranışlarda bulunur & 4 \\
\hline & & Ögrencilerini etiketler & 3 \\
\hline Planlama & 16 & Planlama & 18 \\
\hline Derse hazırlıksız gelir & 9 & Plan ve programı yoktur, gelişi güzel ders yapar & 12 \\
\hline \multirow{3}{*}{ Hazır planları kullanır } & 5 & Hazır planları aynen kullanır & 2 \\
\hline & & $\begin{array}{l}\text { Planları hazırlarken çevre olanaklarını göz önünde } \\
\text { bulundurmaz }\end{array}$ & 1 \\
\hline & & Amaç ve kazanımları dikkate almaz & 1 \\
\hline Öğretme Öğrenme Süreci & 36 & Öğretme Öğrenme Süreci & 44 \\
\hline $\begin{array}{l}\text { Etkinliklerde çocukların ihtiyaçlarını ve farklılıklarını göz } \\
\text { önünde bulundurmaz }\end{array}$ & 9 & $\begin{array}{l}\text { Etkinliklerde ve oyunlarda, çocukların ihtiyaçlarını ve } \\
\text { farklılıklarını göz önünde bulundurmaz }\end{array}$ & 10 \\
\hline Tekdüzedir, hep aynı uygulamaları yapar & 6 & Hep aynı uygulamaları yapar, yenilik yapmaz & 2 \\
\hline Teknolojik araç gereçleri kullanamaz & 3 & Teknolojik araç gereçleri kullanmaz/kullanamaz & 3 \\
\hline Öğrencilerin aktif katılımına olanak sağlayamaz & 3 & Öğrencilerin aktif olmasını engeller & 1 \\
\hline Çocukların sorularına tatmin edici cevaplar veremez & 2 & Çocukların sorularına tatmin edici cevaplar veremez & 3 \\
\hline \multirow[t]{5}{*}{ Sürekli yerinde (masasında) oturur } & 4 & Etkinlikler zaman doldurmak amaçlıdır & 3 \\
\hline & & Etkinlikleri sınıfta hazırlar & 2 \\
\hline & & Neyi nasıl sunacağını bilemez & 3 \\
\hline & & Çocukları motive edemez & 3 \\
\hline & & Plana aşırı bağımlıdır & 2 \\
\hline Sinıf Yönetimi & 25 & Sinıf Yönetimi & 26 \\
\hline Sınıfa hâkim değildir, düzeni sağlayamaz & 11 & Sınıfa hâkim değildir, düzeni sağlayamaz & 10 \\
\hline
\end{tabular}




\begin{tabular}{lrlr} 
Sınıfta düzeni bağırarak sağlamaya çalışır & 5 & Sinıfta düzeni bağıırarak sağlamaya çalışır & 4 \\
Baskıcıdır, katı kuralların dışına çıkamaz & 2 & Baskıcıdır, katı kuralların dışına çıkamaz & 3 \\
& & Sinıf kurallarını koymaz & 2 \\
& & Kuralları uygularken tutarsız davranır & 1 \\
\hline Zaman Yönetimi & $\mathbf{6}$ & Zaman Yönetimi & $\mathbf{6}$ \\
Zamanı iyi kullanamaz & 3 & Zamanı etkili ve verimli kullanmaz & 2 \\
Zamanı boşa harcar & 3 & Zamanı boşa harcar & 2 \\
& & Saatini doldurup gitmeyi bekler & 2 \\
\hline Değerlendirme & $\mathbf{3}$ & Değerlendirme & $\mathbf{4}$ \\
Her çocuktan aynı başarıyı bekler & 3 & Her çocuktan aynı başarıyı bekler & 2 \\
& & Değerlendirme yapmaz & 2 \\
\hline Toplam & $\mathbf{1 9 6}$ & & $\mathbf{2 2 2}$ \\
\hline
\end{tabular}

Açıklama: Temalar altında dönem başında ve sonunda öne çıkan ve farklılık gösteren görüşlere yer verilmiştir.

Tablo 2 incelendiğinde yetersiz öğretmenin özelliklerine ilişkin dönemin başındaki ( $\mathrm{f}=196)$ ve sonundaki ( $\mathrm{f}=222)$ görüşlerin, kişisel özellikler, ögretme ögrenme süreci, sinıf yönetimi, iletişim becerileri, mesleki gelişim, planlama, ögrenciye değer verme ve ögrenciyi tanıma, zaman yönetimi, değerlendirme ve velilerle iletişim başlıklarında gruplandığı görülmektedir. Dönem sonundaki görüşler sayıca artmakla beraber, kategori sayısının değişmediği ancak, ailelerle iletişim boyutunun genişletilerek Okul çevresi ile iletişim görüşünün eklendiği ve bazı boyutlarda içerik olarak farklılaşmalar meydana geldiği dikkat çekmektedir.

Kişisel özellikler etkili öğretmen ile ilgili görüşlerde de olduğu gibi yetersiz bir öğretmen konusunda da en fazla görüş bildirilen temadır. Bu tema altında yer alan görüşler kendi içinde dönem başında ve sonunda benzerlik gösterdiği gibi Tablo 1'de etkili öğretmenin kişisel özellikleri bölümünde belirtilen görüşlerle de benzerlik göstermektedir. Mesleğini, işini severek yapmaz, çocukları sevmez, çocuklara olumsuz bir modeldir, mesleğinden bikmıştır-yorulmuştur hem dönem başında hem de sonunda belirtilen ortak görüşlerdir. Çocukları sevmez görüşünün gözlemler sonrasında azaldığı görülmektedir ancak; dönem sonunda az sayıda da belirtilmiş olması gözlem yapılan öğretmenlerin seçiminin önemini akıllara getirmektedir. Nitekim K:13'ün "öğrencilerinden nefret eder, devlette çalışmak için bu mesleği yapar" şeklindeki ifadesi bu anlamda düşündürücü bir ifadedir. Mesleğinde yorulmuştur/bıkmıştır görüşü de bu bulguyu destekleyen bir görüştür. Ortak belirtilen görüşlerin yanı sıra gözlemler sonrası dönem sonunda mesleğinin öneminin farkinda değildir, empati kuramaz ve dış görünüşüne önem vermez gibi öğretmenliğin farklı yanlarına yönelik görüşler de bildirilmiştir.

Mesleki gelişim boyutunda öğrencilerin dönem başındaki yeterli bilgi ve deneyime sahip olmama ve kendini yenilememe şeklindeki görüşleri dönem sonunda da değişmemiştir. Kendini yenilememe ile ilgili olarak K:13'ün "hep benim zamanında...şeklinde cümleler kurar" ifadesi dikkat çekicidir.

Iletişim becerileri ile ilgili görüşler dönem başında ve sonunda benzerlik göstermektedir. Dönem sonunda ögrrencileri ile sevgi bă̆ı kuramaz görüşü okul öncesi dönemde çocuk-öğretmen iletişimine yönelik önemli bir vurgudur.

Veliler ve okul çevresi ile iletişim boyutunda dönem başında belirtilen görüşler velilerle iyi ilişkiler kuramaz şeklinde sınırlı bir şekilde ele alınırken, dönem sonunda bu görüşe okul çevresi ve veliler ile iletişim kurup etkin bir yapı kuramaz görüşü de eklenmiştir. İletişim boyutundaki bu bulgular Tablo 1'den elde edilen bulgularla örtüşmektedir.

Öğrenciyi tanıma boyutunda dönem sonunda belirtilen görüşlerin dönem sonunda kapsamı genişlememekle beraber sayıca arttı̆̆ görülmektedir. Ögrencileri tanımaz bulgusu ile ilgili olarak K.6’nın "öğrenciye şişşşt, sen! diye seslenen, adını bilmeyen” ifadesi somut bir örnektir.

Ögrenciye değer verme boyutunda dönem sonunda belirtilen görüşlerin sayıca ve içerik olarak farklılaştığı görülmektedir. Bu boyutta, öğrencileri arasında ayrımcılık yapar-eşit adil davranmaz, 
ögrencilerini anlamaz, dönem başında ve sonunda öne çıkan ortak görüşler iken, çocukları kırıcı, rencide edici davranışlarda bulunur ve ögrencilerini etiketler dönem sonunda öne çıkan görüşlerdir. Ayrım yapma ile ilgili olarak K:10'nun “belirli öğrenciler ile ilgilenir”, öğrencileri etiketleme ile ilgili olarak da K:4'ün "problemli çocuklar adına hiçbir şey yapmaz, onları etiketler ve kendi hallerine bırakır" görüşleri dikkat çekicidir.

Planlama ile ilgili olarak öğrencilerin dönem başındaki derse hazırlıksız gelir ve dönem sonundaki plan ve programı yoktur gelişi güzel ders yapar, hazır planları kullanır görüşleri Tablo 1'deki bulgularlar da örtüşmektedir. Haktanır'ın (2008) öğretmenler arasında basılı ve elektronik ortamlardan alınan hazır planların kullanımının yaygın olduğu bulgusu bu bulguyu destekler niteliktedir. Öte yandan planları hazırlarken çevre olanaklarını göz önünde bulundurmaz ve amaç ve kazanımları dikkate almaz görüşleri MEB 2013 Okul Öncesi Eğitimi Programında belirtilen nitelikli bir planın gereklilikleri göz önünde bulundurulduğunda, dikkat çekicidir.

Ögrenme ögretme süreci hem dönem başında hem de dönem sonunda en fazla görüş bildirilen boyuttur. Çocukların ihtiyaçlarını, gelişim özelliklerini ve bireysel farklılıklarını göz önünde bulundurmaz görüşü ile ilgili olarak K:17'nin "çocuğun gelişmesine izin vermeyen, "önemli olan güzel bir ürün ortaya koymaktır" düşüncesine sahiptir" ifadesi öğrencinin süreçteki gelişiminden çok ürüne odaklanılmasına yönelik somut bir örnektir. Etkinlikler zaman doldurmak amaçlıdır, etkinlikleri sınıfta hazırlar, plana aşırı bağımlıdır gibi dönem sonunda etkinlikler ile ilgili olarak belirtilen ek görüşlerdir. Bu görüşler ile ilgili olarak, K:10'un "hazır plana uymak adına çocuğa istemediği bir alanda baskı uygulayan", "hazır planı öğrencinin dikkatini çekmediği halde zorla uygulatan" ve $\mathrm{K}: 4$ 'ün "yapılan etkinliklerin eksik kalması, bazı öğrencilerin hiç yapmaması" ifadeleri hazır planları kullanmanın olumsuz etkilerine dair algıların oluştuğunu göstermesi bakımından önemlidir. Etkinliklerin zaman doldurmak amaçlı olduğuna dair bulgu zaman yönetimi ile ilgili bulgularla, etkinlikleri sınıfta hazırlama ve neyi nasıl sunacağını bilememe görüşleri de planlama ile ilgili bulgularla örtüșmektedir.

Sinıf yönetimi ile ilgili olarak öne çıkan görüşler dönem başında ve dönem sonunda paralellik göstermektedir. K:6'nın "sürekli bağırıp, çağıran, sus!, yapma!, otur der" ifadesi sınıfta düzenini bağırarak sağlar görüşüne örnektir. Dönem başındaki görüşlere ek olarak sınıf kurallarını koymaz ve kuralları uygularken tutarsız davranır görüşleri Okul Deneyimi dersini alan öğrencilerin kuralların bilinmesi ve sürekliliğin sağlanmasına yönelik algılarının geliştiğini göstermektedir.

Zaman yönetimi ile ilgili olarak zamanı etkili ve verimli kullanmaz ve boşa harcar görüşleri ifade edilmiştir. K:6'nın “derse hazırlanmadan gelip, çocukları başıboş -bırakıp-gün boyu serbest etkinlikle geçiren" ifadesi zaman yönetimi ile ilgili bulguların yanı sıra, planlama ve öğrenme öğretme sürecine yönelik bulguları destekleyen somut bir ifadedir.

Öğrencilerin yetersiz öğretmenin özelliklerine ilişkin görüşlerinin Tablo 1'de belirtilen etkili bir öğretmeninin özelliklerine ilişkin görüşleri ile paralellik göstermesi öğrencilerin görüşlerindeki tutarlılığ göstermektedir.

Değerlendirme boyutunda her çocuktan aynı başarıyı bekler dönem başında ve sonunda belirtilen ortak bir görüş iken, dönem sonunda değerlendirme yapmaz görüşü de ifade edilmiştir. Oysa MEB 2013 Okul Öncesi Eğitim Programına göre değerlendirme boyutunun çok kapsamlı bir şekilde ele alınması gerekmektedir.

Öğrencilerin yetersiz öğretmenin özelliklerine ilişkin tanımlamalarındaki sayı ve kapsam olarak artış okul deneyimi dersinin etkililiği olarak değerlendirilebilir. Bununla birlikte öğrencilerin algılarının oluşmasında gözledikleri ortamın etkisi de düşünüldüğünde, hem yetersiz öğretmenin kendi içindeki artış hem de ögrenme ögretme süreci ve planlama boyutlarındaki görüşlerin etkili öğretmene yönelik aynı temalardaki görüşlerden fazla olması ve etkili öğretmen ile ilgili olarak değerlendirme boyutunda görüş bildirilmemiş olması, ayrıca araştırma kapsamında yer alan (Ekinci ve Başaran, 2014 
) ancak bu çalışmada verilmemiş olan diğer boyutlarla ( Yetersiz Sınıf D.B:f=182 - D.S: f=244; Verimsiz Ders D.B:f=160 - D.S: f=170 ) birlikte değerlendirildiğinde, gözlem yapılan sınıflardaki uygulama öğretmenlerinin yeterlikleri ile ilgili sıkıntılara ilişkin ipucu şeklinde değerlendirilebilir. Bu durum uygulama öğretmenlerinin karşılaşılan olumsuz özelliklerini ortaya koyan ve nitelikli öğretmen ve eğitim ortamlarının seçilmesini öneren araştırmaların sonuçları ile benzerlik göstermektedir (Azar, 2003;Ergün ve Özdaş, 1999; Oğuz, 2004; Oral ve Dağl1, 1999; Ören, Sevinç ve Erdoğmuş, 2009; Sarıtaş, 2007; Tarman, 2012; Turgut Yılmaz ve Firuzan 2008). Öğrencilerin uygulamada gözlemlediği öğretmenlerin niteliklerine ilişkin, Haktanır'ın (2008) okul öncesi öğretmenlerinin sınıf yönetimi, kişiler arası ilişkiler, çocukla iletişim, çocuklar arası problem çözme, temel kuralların öğretimi, ailelerle sağlıklı ilişkiler ve okul-aile işbirliği konularında yetersiz bulundukları sonucu alana dönük olması ve yukarıdaki görüşü desteklemesi açısından anlamlıdır.

\section{SONUÇ ve ÖNERILLER}

Okul Öncesi Eğitimi Programı öğrencilerinin Okul Deneyimi Dersinin sonunda öğretmenlik mesleğine yönelik olumlu ve olumsuz algılarının sayıca ve kapsam olarak artması öğrencilerin öğretmenlik mesleğine yönelik farkındalıklarının arttı̆̆ını göstermektedir.

Buna ek olarak öğrencilerin öğretmenliğe yönelik tanımlamalarında dönem başında daha çok genel ifadeler kullanırken, dönem sonunda okul öncesi eğitimi alanına dönük ifadeleri kullanmaları kendi alanlarına yönelik farkındalıklarının geliştiğini göstermektedir.

Öte yandan, Okul Deneyimi dersi mesleki gelişim ve planlama, zaman yönetimi temalarına ilişkin algılarda dikkate değer bir farklılık yaratmamıştır. Ayrıca, MEB (2008) okul öncesi öğretmenliği özel alan yeterlikleri göz önünde bulundurulduğunda aile eğitimi etkinliklerini yürütebilme, değerlendirme (öğrenci, öğretmen ve eğitim programı), yaratıcılık ve estetik boyutlarında görüş bildirilmemiş olması dersin bu boyutlara ilişkin farkındalık oluşturmada etkili olamadığını göstermektedir.

Öğrencilerin algılarının oluşmasında gözledikleri ortamın etkisi de düşünüldügünde, yetersiz öğretmene ilişkin görüşlerin olumlu özelliklere göre sayıca daha fazla olması gözlem yapılan uygulama öğretmeni ve sınıfların niteliğinin amaca uygun olmadığını göstermiştir.

$\mathrm{Bu}$ sonuçlara dayalı olarak dersin içeriğinin, öğretmenlik mesleğine yönelik bütüncül bir alg1 oluşturacak şekilde gözden geçirilmesi ve olumlu algıların zenginleşmesi için uygulama okulları, öğretmen ve sınıfların seçiminde özenli yaklaşılması önerilmektedir.

\section{Kaynaklar}

Azar, A. (2003). Okul deneyimi ve öğretmenlik uygulaması derslerine ilişkin görüşlerinin yansımaları. Milli Ĕgitim Dergisi, 159.

Bilgin, H. (2010). Okul öncesi eğitimde aile ile iletişim ve ailelere rehberlik. G.U.Balat (Ed.). Okul öncesi eğitime giriş. (s. 208-219). Ankara: Pegem Akademi.

Creswell, J. W. (2005). Educational research: Planning, conducting, and evaluating quantitative and qualitative research (Second edition). New Jersey: Pearson Education, Inc. Demircan, C. (2007).

Çiçek, F., Başaran, S. T., Demirbaş, A. ve Maden, C. (2001). Çağgaş öğretmen profili. Milli Eğitim Basımevi, Ankara.

Demircan, C. (2007).Okul deneyimi II dersine yönelik öğrenci görüşlerinin incelenmesi (Mersin Üniversitesi Örneği). Mersin Üniversitesi Ĕgitim Fakültesi Dergisi, 3 (2),119-132.

Ekinci, N. ve Başaran, S.T. (2014). Okul deneyimi dersinin öğrencilerin öğretmenlik algılarına etkisi. 
Öğretmen Yetiştirme Politika ve Sorunlart Uluslar Arası Sempozyumu IV-Ispıte 2014. http://www.ispite2014.hacettepe.edu.tr/bildiriler kitabi.pdf. Erişim:30/06/2014

Ergün, M. ve Özdaş, Ali.(1999) Okul Gözlemi ve Uygulama Çalışmalarının Öğretmen Adayları Üzerindeki Etkisi. AKÜ. Sosyal Bilimler Dergisi, 3.

Haktanır, G. (2008). Okul öncesi öğretmeni’nin niteliği. Ĕgitime Bakış Eğitim-Öğretim ve Bilim Araştırma Dergisi, 4(12), 22-35

Kavas, B. A. ve Bugay, A. (2009). Öğretmen adaylarının hizmet öncesi eğitimde gördükleri eksiklikler ve çözüm önerileri. Pamukkale Üniversitesi Eğitim Fakültesi Dergisi Y11, 1, 25, 13-21.

Kvale, S. (1996). Interviews: An introduction qualitative research interviewing. London: Sage Publication Ltd.

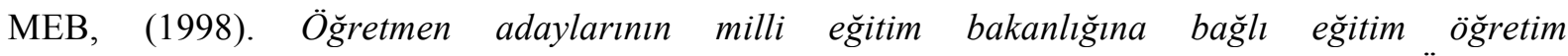
kurumlarında yapacakları ögretmenlik uygulamasına ilişkin yönerge. Ankara: Öğretmen Yetiştirme ve Eğitimi Genel Müdürlüğü.

MEB, (2008). Öğretmen yeterlikleri. Devlet Kitapları Müdürlüğü, Ankara

Oğuz, A. (2004). Okul deneyimi I dersinin öğretmen adayları üzerindeki etkileri. Dumlupınar Üniversitesi Sosyal Bilimler Dergisi, 11, 141-162.

Oral, B. ve Dağlı, A. (1999). Öğretmen adaylarının okul deneyimine ilişkin algıları. Çă̆daş Ĕ̆itim, $254(18-24)$.

Ören, F. Ş., Sevinç, Ö. S. ve Erdoğmuş, E. (2009). Öğretmen adaylarının okul deneyimi derslerine yönelik tutumlarının ve görüşlerinin değerlendirilmesi. Kuram ve Uygulamada Ĕ̆itim Yönetimi, $2009,15,58,217-246$.

Özdemir, A. Ş. ve Çanakçı, O. (2005). Okul deneyimi I dersinin, öğretmen adaylarının öğretimöğrenme kavramlarına ve öğretmen-öğrenci rollerine bakıș açıları üzerindeki etkileri. İlköğretim Online Dergisi,Journal of Elementary Education Online, 1, 4, 73-80.

Sarıtaş, M. (2007). Okul Deneyimi I uygulamasının aday öğretmenlere sağladığı yararlar konusundaki görüşlerin değerlendirilmesi. Uludă̆ Üniversitesi Ĕ̆itim Fakültesi Dergisi, 1, 121-143

Selçuk, Z. (2001). Okul deneyimi ve uygulama. Öğretmen ve öğrenci davranışlarının gözlenmesi (2. Baskı). Ankara: Nobel Yayın Dağıtım.

Sözer, E. (1990). Öğretmen yetiştirmeye ilişkin genel kavram ve ölçütlerin üniversitelerimizdeki uygulamalara yansıması. Anadolu Üniversitesi Ĕ̆itim Fakültesi Dergisi, 3,2: 55-66.

Tagay, Ö. (2014). Okul öncesi eğitimde çocuğu tanımanın önemi. A.Önder (Ed). Okul öncesi dönemde çocukları değerlendirme ve tanıma teknikleri. (s. 2-8). Ankara: Pegem Akademi.

Tarman, B. (2012). Öğretmenlik deneyimi dersinin öğretmen adaylarının öğretmenlik mesleğine yönelik inançlarına etkisi. Kuram ve Uygulamada Ĕ̈itim Bilimleri, 12, (3).

Teddlie, C. ve Tashakkori, A. (2009). Foundations of mixed methods research: Integrating quantitative and qualitative approaches in the social and behavioral sciences. USA: SAGE Publications, Inc.

Turgut, M., Yılmaz, S. ve Firuzan, A. R. (2008). Okul Deneyimi uygulama sürecinin değerlendirilmesi üzerine bir araştırma. Üniversite ve Toplum,8 (2).

Yıldırım, A. ve Şimşek, H. (2013). Sosyal bilimlerde nitel araştırma yöntemleri (9. Genişletilmiş Bask1). Ankara: Seçkin Yayıncılık.

YÖK.(1998). Ĕ̌itim fakültesi öğretmen yetiştirme lisans programları . Ankara. 
MSKU Ĕ̈itim Fakültesi Dergisi MSKU Journal of Education

ISSN 2148-6999 Cilt-Volume 2, Sayz-Number 1, 2015

Yrd. Doç. Dr. Necla EKİNCİ Muğla Sttkı Koçman Üniversitesi Eğitim

Fakültesi

E-mail: nekinci@mu.edu.tr

Semra TICAN BAŞARAN

Muğla S1tkı Koçman Üniversitesi Eğitim

Fakültesi

E-mail: semrabasaran@mu.edu.tr 